\title{
Streptococcus phocae sp. nov., a New Species Isolated from Clinical Specimens from Seals
}

\author{
IDA SKAAR, ${ }^{1 *}$ PETER GAUSTAD, ${ }^{2}$ TONE TøNJUM,${ }^{2}$ BJØRG HOLM,${ }^{2}$ AND HENRIK STENWIG ${ }^{1}$ \\ Central Veterinary Laboratory, State Veterinary Laboratories of Norway, N-0033 Oslo, ${ }^{1}$ and Kaptein W. Wilhelmsen \\ og Frues Bakteriologiske Institutt, University of Oslo, Rikshospitalet, N-0027 Oslo, ${ }^{2}$ Norway
}

\begin{abstract}
A new beta-hemolytic streptococcal species, Streptococcus phocae, was isolated from organ specimens obtained from seals. This taxon is described on the basis of the results of a study of 22 strains. $S$. phocae was serologically somewhat heterogeneous (group antigen -/F/C). Strains belonging to this species exhibited high levels of DNA-DNA homology to each other, as determined by DNA-DNA hybridization, but low levels of DNA-DNA homology to the type strains of other streptococcal species. A simple scheme for the differentiation of $S$. phocae from other beta-hemolytic streptococci is presented. Strain 8399 H1 (= NCTC 12719) is the type strain of $S$. phocae.
\end{abstract}

Streptococci have received much attention because of the large number of infections that they cause in humans and animals. These organisms constitute one of the major groups of bacteria that inhabit respiratory systems. Isolation of Streptococcus species (alpha-hemolytic, beta-hemolytic, or nonhemolytic) from seals with pneumonia or septicemia has been reported several times. Authors have described isolates that resemble Streptococcus canis $(2,3,21)$, Streptococcus zooepidemicus isolates (2), and beta-hemolytic streptococcal isolates without any further identification $(1,8,19)$.

During the summer 1988, there was an epizootic outbreak among harbor seals (Phoca vitulina) in northwestern Europe caused by a morbillivirus that is antigenically related to canine distemper virus and is called phocine distemper virus. This disease killed more than 18,000 harbor seals and a small number of grey seals (Haliochoerus grypus) (10). In many cases, the final cause of death of seals infected with phocine distemper virus was infection with one or more opportunistic bacterial pathogens. Beta-hemolytic streptococci were isolated from seals from Scotland (16), England, The Netherlands, Germany (10), Denmark (11), Sweden (5), and Norway (13). The most common signs that were observed clinically were dyspnoea, coughing, and nasal discharge. Fifty-four seals were autopsied at the State Veterinary Laboratories of Norway, Central Veterinary Laboratory, in 1988. The most common gross lesions found were pneumonia with areas of consolidation, purulent exudate in the bronchi, interlobular edema, and emphysema (13).

In this paper, we describe the characteristics of streptococcal isolates obtained from dead seals. These strains were classified in the genus Streptococcus as a new species, Streptococcus phocae. The type strain of this species is strain $8399 \mathrm{H} 1$.

\section{MATERIALS AND METHODS}

Samples. Organ samples from 37 seals were examined bacteriologically, and beta-hemolytic streptococci were the bacteria isolated most frequently from lung specimens. Betahemolytic streptococci were also isolated from livers, spleens, and kidneys, indicating that the seals had a septicemic condition.

\footnotetext{
* Corresponding author. Mailing address: Central Veterinary Laboratory, State Veterinary Laboratories of Norway, Box 8156 Dep., N-0033 Oslo, Norway. Phone: 4722964500 . Fax: 4722460034 .
}

Bacterial strains. A total of 34 streptococcal strains were isolated from seals suffering from pneumonia; 22 of these strains were included in this study. The type strains of various Streptococcus species were purchased from the following institutions: American Type Culture Collection (ATCC), Rockville, Md.; Deutsche Sammlung von Mikroorganismen (DSM), Braunschweig, Germany; National Collection of Dairy Organisms (NCDO), Reading, United Kingdom; and National Collection of Type Cultures (NCTC), London, United Kingdom. We selected Streptococcus gordonii NCTC 3165 and Streptococcus sanguis NCTC $7863^{\mathrm{T}}$ ( $\mathrm{T}=$ type strains) as representatives of the $S$. sanguis group and Streptococcus constellatus ATCC $27823^{T}$, Streptococcus intermedius NCTC $27335^{\mathrm{T}}$, and Streptococcus milleri NCTC $10708^{\mathrm{T}}$ as representatives of the $S$. milleri group. We also included Streptococcus equi subsp. zooepidemicus NCTC $4676^{\mathrm{T}}$ in this study. The type strains used are listed in Table 1.

Media and cultivation. The specimens were cultivated on blood agar plates (Difco Laboratories, Detroit, Mich.) in a normal atmosphere, in an atmosphere containing $10 \%$ carbon dioxide, and in an anaerobic atmosphere $\left(85 \% \mathrm{~N}_{2}, 10 \% \mathrm{H}_{2}\right.$, $5 \% \mathrm{CO}_{2}$ ) for 18 to $24 \mathrm{~h}$ at $37^{\circ} \mathrm{C}$. The inocula used for biochemical tests were prepared from overnight cultures. All test preparations were incubated at $37^{\circ} \mathrm{C}$. Inocula were also incubated at 10 and $45^{\circ} \mathrm{C}$ to test for growth.

Morphological and colonial characteristics. Colony morphology was observed on blood agar plates. Cell morphology was determined by using Gram-stained smears and electron microscopy. Motility was examined by using phase-contrast microscopy and cultures grown in Todd-Hewitt broth (Difco). The ability to produce spores was investigated by inoculating a culture into Todd-Hewitt broth, heating the preparation at $80^{\circ} \mathrm{C}$ for $20 \mathrm{~min}$, and then incubating it at $37^{\circ} \mathrm{C}$ overnight.

Biochemical characteristics. The ability to produce acid from various carbohydrates under aerobic conditions was determined by using the standard broth method, an API $50 \mathrm{CH}$ kit, and an API 20 Strep kit (API System, La Balme-lesGrottes, France). The broth used contained $25 \mathrm{~g}$ of heart infusion broth (Difco) in 1,000 ml of distilled water, $12 \mathrm{ml}$ of $0.2 \%$ bromthymol blue ( $1 \mathrm{~g}$ of bromthymol blue, $25 \mathrm{ml}$ of 0.1 $\mathrm{M} \mathrm{NaOH}, 475 \mathrm{ml}$ of distilled water), and carbohydrate at a final concentration of $0.8 \%$. The API $50 \mathrm{CH}$ test and the API 20 Strep test were performed according to the manufacturer's instructions and were read after $4,24,48$, and $72 \mathrm{~h}$ and 7 days. The enzymatic tests and the tests for production of acid from various carbohydrates were read after 4 and $24 \mathrm{~h}$, respectively. 
TABLE 1. RBRs, as determined by DNA-DNA hybridization, between radioactively labelled DNAs from $S$. phocae strains $(8190$

$\mathrm{R} 2,8399 \mathrm{H} 1^{\mathrm{T}}$, and $8026 \mathrm{~L} 2$ ) and $S$. iniae ATCC $29128^{\mathrm{T}}$ and unlabelled DNAs from strains of $S$. phocae and other Streptococcus spp.

\begin{tabular}{|c|c|c|c|c|}
\hline \multirow[b]{2}{*}{ Strain } & \multicolumn{4}{|c|}{ RBR (\%) with: } \\
\hline & $\begin{array}{c}\text { S. phocae } \\
8190 \text { R2 }\end{array}$ & $\begin{array}{l}\text { S. phocae } \\
8399 \mathrm{H1}^{\mathrm{T}}\end{array}$ & $\begin{array}{c}\text { S. phocae } \\
8026 \mathrm{~L} 2\end{array}$ & $\begin{array}{c}S . \text { iniae } \\
\text { ATCC } \\
29128^{\mathrm{T}}\end{array}$ \\
\hline \multicolumn{5}{|l|}{ S. phocae strains } \\
\hline 7908 P2 & 130 & 86 & 89 & 4 \\
\hline $8026 \mathrm{~L} 2$ & 103 & 54 & 100 & 2 \\
\hline $8056 \mathrm{P} 2$ & 83 & 86 & 60 & 2 \\
\hline 8059 P2 & 60 & 77 & 76 & 3 \\
\hline 8093 & 66 & 50 & 71 & 5 \\
\hline $8189 \mathrm{R} 2$ & 46 & 73 & 83 & 1 \\
\hline $8190 \mathrm{R} 2$ & 100 & 66 & 64 & 5 \\
\hline 8202 P3 & 111 & 49 & 52 & 5 \\
\hline $8205 \mathrm{H} 2$ & 42 & 145 & 120 & 2 \\
\hline 8252 & 83 & 81 & 122 & 8 \\
\hline 8287 & 61 & 70 & 136 & 0 \\
\hline 8319 & 103 & 139 & 99 & 6 \\
\hline $8399 \mathrm{H}^{\mathrm{T}}$ & 70 & 100 & 63 & 2 \\
\hline 8408 P2 & 96 & 124 & 103 & 3 \\
\hline \multicolumn{5}{|l|}{ Strains of other Streptococcus spp. } \\
\hline S. agalactiae NCTC $8181^{\mathrm{T}}$ & 0 & 2 & 2 & 0 \\
\hline S. canis DSM $20715^{\mathrm{T}}$ & 1 & 1 & 2 & 1 \\
\hline S. constellatus ATCC $27823^{\mathrm{T}}$ & 0 & 0 & 1 & 0 \\
\hline S. dysgalactiae NCDO $2023^{\mathrm{T}}$ & 3 & 3 & 4 & 4 \\
\hline S. equi $\mathrm{NCTC} 9682^{\mathrm{T}}$ & 3 & 4 & 6 & 3 \\
\hline $\begin{array}{l}\text { S. equi subsp. zooepidemicus } \\
\text { NCTC } 4676^{\mathrm{T}}\end{array}$ & 1 & 3 & 3 & 4 \\
\hline S. gordonii NCTC 3165 & 1 & 0 & 0 & 0 \\
\hline$S$. iniae ATCC $29128^{\mathrm{T}}$ & 6 & 3 & 16 & 100 \\
\hline S. intermedius NCTC $27335^{\mathrm{T}}$ & 1 & 0 & 0 & 0 \\
\hline S. milleri NCTC $10708^{\mathrm{T}}$ & 0 & 0 & 1 & 0 \\
\hline S. mutans NCTC $10449^{\mathrm{T}}$ & 1 & 0 & 1 & 1 \\
\hline S. pneumoniae NCTC $7465^{\mathrm{T}}$ & 1 & 0 & 1 & 0 \\
\hline S. porcinus NCTC $10999^{\mathrm{T}}$ & 1 & 1 & 1 & 2 \\
\hline S. salivarius ATCC $13419^{\mathrm{T}}$ & 1 & 0 & 0 & 0 \\
\hline S. sanguis NCTC $7863^{\mathrm{T}}$ & 0 & 0 & 0 & 0 \\
\hline S. suis NCTC $10235^{\mathrm{T}}$ & 0 & 1 & 3 & 4 \\
\hline
\end{tabular}

Hydrolysis of arginine was determined in arginine dihydrolase medium ( $3 \mathrm{~g}$ of yeast extract [Difco], $1 \mathrm{~g}$ of glucose, $5 \mathrm{~g}$ of arginine, $0.02 \mathrm{~g}$ of bromcresol purple, and enough distilled water to bring the volume up to $1,000 \mathrm{ml}$ ) and by using the test in the API 20 Strep kit. Hydrolysis of esculin was determined both by the test in the API 20 Strep kit and by inoculating esculin medium $(100 \mathrm{ml}$ of heart infusion broth, $0.55 \mathrm{~g}$ of esculin) and adding 1 drop of $\mathrm{FeCl}_{3}$ after incubation for $24 \mathrm{~h}$. Hydrolysis of hippurate was determined both by the test in the API 20 Strep kit and by inoculating hippurate medium $(5 \mathrm{~g}$ of meat extract [Difco], $1 \mathrm{~g}$ of yeast extract, $10 \mathrm{~g}$ of peptone, $5 \mathrm{~g}$ of $\mathrm{NaCl}, 2 \mathrm{~g}$ of $\mathrm{Na}_{2} \mathrm{HPO}_{4}$, enough distilled water to bring the volume up to $1,000 \mathrm{ml}, 1 \%$ sodium hippurate) and adding $50 \%$ $\mathrm{H}_{2} \mathrm{SO}_{4}$ at a 1:1 ratio after incubation for 4 to 5 days. Starch hydrolysis was evaluated by inoculating Mueller-Hinton agar (Difco) and flooding the plates with iodine after $24 \mathrm{~h}$. Acetoin production was determined both by the test in the API 20 Strep kit and in Voges-Proskauer medium (10 $\mathrm{g}$ of tryptose, $3 \mathrm{~g}$ of Lab-Lemco [Oxoid, Ltd., Basingstoke, England], $1 \mathrm{~g}$ of yeast extract, $20 \mathrm{~g}$ of glucose, $1,000 \mathrm{ml}$ of distilled water) by adding 4 drops of alpha-naphthol (alcoholic) and 2 drops of $40 \%$ $\mathrm{KOH}$. Production of alkaline phosphatase was determined both by the test in the API 20 Strep kit and in phosphate broth
(100 $\mathrm{ml}$ of heart infusion broth, 1 ampulla of phenolphthalein phosphate [Oxoid]) containing 1 drop of $1 \mathrm{~N} \mathrm{NaOH}$, which was added after incubation for $24 \mathrm{~h}$. Production of $\beta$-glucuronidase and production of pyrrolidonylarylamidase were determined by the API 20 Strep tests. Catalase activity was determined by placing a small amount of a plate culture into 1 drop of $3 \%$ $\mathrm{H}_{2} \mathrm{O}_{2}$. Hyaluronidase activity was determined on blood agar that was inoculated with a Pasteurella multocida type A strain and with a streak of a test strain and then incubated for $24 \mathrm{~h}$. The capsular hyaluronic acid of type A strains was depolymeried by hyaluronidase (manifested as a reduction in the size of the Pasteurella colonies in the region adjacent to the streptococcal streak) (6). The optochin susceptibility test was performed by placing an optochin tablet (Neo-Sensitabs; Rosco, Copenhagen, Denmark) on a densely inoculated blood agar plate. The sizes of inhibition zones were determined after $24 \mathrm{~h}$ of aerobic incubation; inhibition zones more than $12 \mathrm{~mm}$ in diameter indicated that a strain was susceptible to optochin. Bacitracin resistance was determined by flooding a ToddHewitt plate with a bacterial suspension, removing the superfluous liquid, and drying the plate at $37^{\circ} \mathrm{C}$ for $30 \mathrm{~min}$ before a bacitracin tablet (0.04 IU; Neo-Sensitabs) was added. Inhibition zones were then measured after aerobic incubation for 24 $\mathrm{h}$; inhibition zones more than $15 \mathrm{~mm}$ in diameter indicated that a strain was susceptible to bacitracin. Salt tolerance was determined by the presence or absence of growth in inoculated Todd-Hewitt broth with and without $6.5 \% \mathrm{NaCl}$ after $24 \mathrm{~h}$ of incubation. Growth in bile was detected in inoculated ToddHewitt broth supplemented with $40 \%$ bile after $24 \mathrm{~h}$ of incubation.

Serological characteristics. All strains were examined serologically with a Streptex kit (Wellcome Diagnostics, Dartford, England), by the standard method described by Lancefield (14), and by the double diffusion test. The composition of the diffusion gel used was as follows: $1 \mathrm{~g}$ of Bacto Agar (Difco), 25 $\mathrm{ml}$ of phosphate buffer ( $\mathrm{pH} \mathrm{6.5)}$, and $70 \mathrm{ml}$ of distilled water. The gel with its walls filled by serum and the test strains was incubated at $4^{\circ} \mathrm{C}$ for $24 \mathrm{~h}$ before precipitation lines were read. For the alternative examination Lancefield grouping sera $\mathrm{A}$ through V (Wellcome) were used.

DNA-DNA hybridization. DNAs from 14 of the 22 strains included in this study were subjected to a hybridization analysis. DNA-DNA hybridization was performed essentially as described previously (22), except that DNA was extracted by the method of Coykendall (7). The concentration of DNA was adjusted to $200 \mu \mathrm{g} / \mathrm{ml}$.

(i) Dot blot filters. Eight parallel dots of each singlestranded genomic DNA and a Tris-EDTA buffer control were blotted onto nitrocellulose filters by using the Hybri-Dot System (Bethesda Research Laboratories, Gaithersburg, Md.) and the method of Katafos et al. (12). The filters were stored dry.

(ii) Labelling of probe DNA. Mechanically fragmented genomic DNA probes were labelled with $\left[{ }^{32} \mathrm{P}\right] \mathrm{dCTP}$ to a specific activity of $1 \times 10^{8} \mathrm{cpm} / \mu \mathrm{g}$ of DNA by using a random priming labelling kit (Amersham International plc, Buckinghamshire, England) according to the manufacturer's recommendations.

(iii) Hybridization. Hybridization was performed at $65^{\circ} \mathrm{C}$ in a plastic bag for up to $16 \mathrm{~h}$. The sodium salt concentration of the prehybridization and hybridization fluids was $0.1 \mathrm{M}$. Hybridization washes were performed at $65^{\circ} \mathrm{C}$ at a sodium salt concentration of $0.1 \mathrm{M}$. The results of the dot blot hybridization experiments were obtained by overnight autoradiography (Hyperfilm MP; Amersham) and scintillation counting (Packard Instrument Co., Inc., Meriden, Conn.) of standard cut 
pieces of the nitrocellulose filter, which were cut with a vacuum cutting device which we designed.

(iv) Quantification of the dot blot hybridization reaction mixtures. We determined the mean counts per minute for eight parallel reaction mixtures minus the control counts per minute for salmon sperm DNA for each of the strains. The mean value obtained for the autologous strain by definition represented a DNA homology ratio or a relative binding ratio (RBR) of $100 \%$. The mean RBR for each strain was calculated by dividing the mean counts per minute for the strain by the mean counts per minute for the autologous reaction and multiplying the result by 100 .

G+C-ratio. The guanine-plus-cytocine $(\mathrm{G}+\mathrm{C})$ content of strain $8399 \mathrm{H}^{\mathrm{T}}$ DNA was determined by the method of Marmur and Doty (15).

\section{RESULTS AND DISCUSSION}

Physiological and biochemical characteristics. The 22 strains which we studied were all facultatively anaerobic, catalase-negative, nonmotile, gram-positive cocci that formed chains when they were grown in liquid media. The biochemical characteristics of these 22 strains are shown in Table 2 . Biochemically, the strains appeared to be very homogeneous; 16 of them reacted identically in all of the biochemical tests employed. None of the strains produced acetoin. They all produced acid from D-fructose, maltose, D-mannose, $N$-acetylglucosamine, and ribose, but failed to produce acid from inulin, lactose, mannitol, D-raffinose, salicin, sorbitol, and trehalose. Four strains also produced acid from amidon and glycogen; one of these strains hydrolyzed starch. Two additional strains produced acid from glycerol, lactose, saccharose, melezitose, and D-turanose; one of these two strains also produced acid from galactose. One strain produced pyrrolidonylarylamidase. All of the strains exhibited inhibition zones of $\geq 30 \mathrm{~mm}$ with bacitracin tablets. None of the strains grew in $6.5 \% \mathrm{NaCl}$ broth or in the presence of $40 \%$ bile. None of the strains grew after incubation at 10 and $45^{\circ} \mathrm{C}$.

Serological characteristics. Five strains precipitated in the presence of antiserum $\mathrm{C}$, and the rest of the strains did not react with any of the Lancefield test sera. Antigens of the 13 strains coagglutinated with antiserum $F$ in the Streptex system. The strains which reacted with antiserum $\mathrm{C}$ in the Lancefield system reacted with antiserum $C$ in the Streptex system as well. Four of the strains did not react with any group antiserum.

DNA-DNA hybridization. Table 1 shows the mean RBRs for DNAs from seal streptococci and reference strains of previously described streptococcal species that were hybridized with total genomic DNAs from streptococci isolated from seals (8190 R2, $\left.8399 \mathrm{H1}^{\mathrm{T}}, 8026 \mathrm{~L} 2\right)$ and Streptococcus iniae ATCC $29128^{\mathrm{T}}$ used as probes. The total genomic DNAs from streptococcal strains $8190 \mathrm{R} 2,8399 \mathrm{H}^{\mathrm{T}}$, and $8026 \mathrm{~L} 2$ exhibited mean RBRs with DNAs from other seal strains ranging from 42 to $130 \%$, from 49 to $145 \%$, and from 52 to $136 \%$, respectively (Table 1). The strains were also compared with type and reference strains of other Streptococcus species.

$\mathbf{G}+\mathbf{C}$-ratio. The $\mathrm{G}+\mathrm{C}$ content of the DNA of strain 8399 $\mathrm{H} 1^{\mathrm{T}}$ was $38.6 \mathrm{~mol} \%$.

Biochemically, the strains isolated from seals were very homogeneous. The phenotypic characteristics of these organisms were typical of the genus Streptococcus. The results of our biochemical examinations indicated that the 22 strains which we studied were different from other beta-hemolytic streptococci (Table 3).

Serologically, the strains seemed to be somewhat heterogeneous. The procedures used to extract group antigens were
TABLE 2. Biochemical characteristics of $22 S$. phocae strains and type strain $8399 \mathrm{H} 1$

\begin{tabular}{|c|c|c|}
\hline Characteristic & $\begin{array}{c}\text { No. of } \\
\text { strains } \\
\text { positive }^{a}\end{array}$ & $\begin{array}{l}\text { Reaction of } \\
\text { S. phocae } \\
8399 \mathrm{H1}^{\mathrm{T}}\end{array}$ \\
\hline \multicolumn{3}{|l|}{ Acid produced from: } \\
\hline Amidon & 4 & - \\
\hline D-Fructose & 22 & + \\
\hline Inulin & 0 & - \\
\hline Galactose & 1 & - \\
\hline Glycerol & 2 & - \\
\hline Glycogen & 4 & - \\
\hline Lactose & 0 & - \\
\hline Maltose & 22 & + \\
\hline Mannitol & 0 & - \\
\hline D-Mannose & 22 & + \\
\hline Melezitose & 2 & - \\
\hline$N$-Acetylglucosamine & 22 & + \\
\hline D-Raffinose & 0 & - \\
\hline Ribose & 22 & + \\
\hline Saccharose & 2 & - \\
\hline Salicin & 0 & - \\
\hline Sorbitol & 0 & - \\
\hline Trehalose & 0 & - \\
\hline D-Turanose & 2 & - \\
\hline \multicolumn{3}{|l|}{ Hydrolysis of: } \\
\hline Arginine & 0 & - \\
\hline Esculin & 0 & - \\
\hline Hippurate & 0 & - \\
\hline Starch & 1 & - \\
\hline Voges-Proskauer reaction & 0 & - \\
\hline \multicolumn{3}{|l|}{ Production of: } \\
\hline Alkaline phosphatase & 21 & + \\
\hline$\beta$-Glucuronidase & 0 & - \\
\hline Catalase & 0 & - \\
\hline Hyaluronidase & 0 & - \\
\hline Pyrrolidonylarylamidase & 1 & - \\
\hline Beta-hemolysis & 22 & + \\
\hline Susceptibility to optochin & 0 & - \\
\hline Susceptibility to bacitracin & 22 & + \\
\hline Salt tolerance & 0 & - \\
\hline Growth in the presence of $40 \%$ bile & 0 & - \\
\hline Growth at $10^{\circ} \mathrm{C}$ & 0 & - \\
\hline Growth at $45^{\circ} \mathrm{C}$ & 0 & - \\
\hline
\end{tabular}

${ }^{a} \mathrm{~A}$ total of 22 strains were tested.

different for the Streptex system and the Lancefield method. An enzyme extraction method was used in the Streptex system, while acid extraction was used in the agglutination technique. In addition, the sera used in the two methods were somewhat different. Lancefield antisera $\mathrm{A}$ through $\mathrm{V}$ were crude rabbit sera (14), while in the Streptex system polystyrene latex particles were coated with purified rabbit antibodies. This might explain the lack of uniformity in the serological results.

Genetically, the highest level of heterologous affinity was the RBR of $16 \%$ observed with DNA from $S$. iniae, the species the most frequently isolated from dolphins (17). The strains isolated from seals were clearly distinguished from all other type strains compared (RBRs, $6 \%$ or less). Despite the variations in the RBRs of the streptococcal strains isolated from seals, which could have been due to variations in DNA quality and the very stringent conditions used $(9,18)$, the DNAs of these strains were distinctly separated from the DNAs of all previously described streptococcal species investigated.

The phenotypic and genotypic homogeneity of the strains isolated from seals and the differences between these strains and other species in the genus Streptococcus provided substan- 
TABLE 3. Biochemical and serological characteristics that differentiate $S$. phocae sp. nov. from other beta-hemolytic Streptococcus species

\begin{tabular}{|c|c|c|c|c|c|c|c|c|}
\hline Characteristic & S. phocae & S. iniae & S. canis & S. equi & S. pyogenes & S. agalactiae & $\begin{array}{c}S . \\
\text { porcinus }\end{array}$ & $\begin{array}{l}S . \text { milleri } \\
\text { group }\end{array}$ \\
\hline \multicolumn{9}{|l|}{ Acid produced from: } \\
\hline Inulin & $-{ }^{a}$ & - & - & - & - & - & - & \\
\hline Lactose & - & + & + & - & + & $\mathrm{d}$ & $\mathrm{d}$ & \\
\hline Mannitol & - & + & - & - & - & - & + & \\
\hline D-Raffinose & - & - & - & - & - & - & - & \\
\hline Ribose & + & + & + & - & - & + & + & \\
\hline Salicin & - & + & NT & + & + & $\mathrm{d}$ & + & \\
\hline Sorbitol & - & - & - & - & - & - & + & + \\
\hline Trehalose & - & + & + & - & + & + & + & + \\
\hline \multicolumn{9}{|l|}{ Hydrolysis of: } \\
\hline Arginine & - & NT & + & + & + & + & + & + \\
\hline Esculin & - & + & - & d & $\mathrm{d}$ & - & + & + \\
\hline Hippurate & - & - & - & - & - & + & - & - \\
\hline Voges-Proskauer reaction & - & NT & - & - & - & + & + & + \\
\hline \multicolumn{9}{|l|}{ Production of: } \\
\hline Alkaline phosphatase & + & NT & + & + & + & + & + & \\
\hline$\beta$-Glucuronidase & - & NT & + & + & $\mathrm{d}$ & $\mathrm{d}$ & + & \\
\hline Pyrrolidonylarylamidase & - & NT & - & - & + & - & - & \\
\hline Beta-hemolysis & + & + & + & + & + & + & + & $+^{b}$ \\
\hline Susceptibility to optochin & - & - & - & - & - & - & - & \\
\hline Susceptibility to bacitracin (0.04 IU) & + & - & - & - & + & - & - & - \\
\hline Lancefield group & $-/ \mathrm{F} / \mathrm{C}$ & - & G & $\mathrm{C}$ & A & $\mathrm{B}$ & E,P,U,V & $-/ \mathrm{F} / \mathrm{A} / \mathrm{C} / \mathrm{G}$ \\
\hline
\end{tabular}

$a_{-}, 90 \%$ or more of the strains are negative; $d, 11$ to $89 \%$ of the strains are positive;,$+ 90 \%$ or more of the strains are positive; NT, not tested.

${ }^{b}$ A total of $5 \%$ of the strains are alpha-hemolytic or nonhemolytic.

tial evidence that the Streptococcus strains isolated from seals belong to a species which has not been described previously. The name which we propose for this species is Streptococcus phocae.

Description of Streptococcus phocae sp. nov. Streptococcus phocae (pho'cae. L. gen. n. phocae, of a seal). The description of $S$. phocae below is based on the characteristics of 22 strains. The cells are gram-positive cocci that are $1 \mu \mathrm{m}$ in diameter and occur singly, in pairs, or in chains. Nonmotile. Non-spore forming. Colonies on blood agar are circular, entire, and slightly convex with smooth and glistening surfaces. Unpigmented. The colonies range from pinpoint up to $0.8 \mathrm{~mm}$ in diameter after aerobic incubation at $37^{\circ} \mathrm{C}$ for $24 \mathrm{~h}$. Facultatively anaerobic. Produces $\beta$-hemolysin. Biochemical characteristics are shown in Table 1. All strains produce acid from D-fructose, D-glucose, D-mannose, maltose, $N$-acetylglucosamine, and ribose. Some strains produce acid from D-turanose, glycerol, lactose, melezitose, and saccharose. No acids are produced from 5 -ketogluconate, arabinose, $\beta$-gentobiose, inositol, inulin, L-fucose, mannitol, sorbitol, trehalose, or xylose within 7 days.

Description of the type strain. Type strain $8399 \mathrm{H} 1$ was isolated from the liver of a seal. Its characteristics are identical to those described above and shown in Table 2.

Characteristics which differentiate $S$. phocae from other related streptococcal species. Selected biochemical characteristics that are useful for identification of $S$. phocae and separation of this taxon from other beta-hemolytic streptococcal species are shown in Table 3 (17). S. phocae is easily differentiated from all other beta-hemolytic streptococci except Streptococcus equi subsp. equi by its failure to produce acid from trehalose. It is distinguished biochemically from $S$. equi subsp. equi by the production of acid from ribose and by its inability to produce acid from salicin and to hydrolyze arginine. Streptococcus pyogenes exhibits inhibition zones of $>15 \mathrm{~mm}$ with bacitracin tablets ( $0.04 \mathrm{IU})$, while most beta-hemolytic streptococci belonging to other groups exhibit smaller inhibition zones (20). The streptococcal strains isolated from seals are all susceptible to bacitracin; in this study, however, other biochemical characteristics (Table 3 ) clearly separated these strains from $S$. pyogenes. So far, strains belonging to the $S$. milleri group are the only streptococcal species known to exhibit the F antigen. Biochemically and on the basis of DNA similarity levels, strains belonging to the $S$. milleri group clearly differ from the strains isolated from seals by production of arginine dihydrolase and acetoin (Tables 1 and 3). S. iniae, the most closely related species genetically, is easily differentiated from $S$. phocae by biochemical characteristics (Table 3 ).

Baker et al. described six different Streptococcus types isolated from different organs of grey seal pups (4). Types 1, 2, and 5 produced $\beta$-hemolysin. It is possible that Streptococcus type 1 is genetically related to $S$. phocae.

\section{ACKNOWLEDGMENTS}

We thank to Øystein Evensen and Gunnar Holt, Central Veterinary Laboratory, Oslo, Norway, for performing the autopsies, Steinar Høie, Central Veterinary Laboratory, Oslo, Norway, for bacteriologically examining the organ samples, and Vigdis Thorsvik, University of Bergen, Bergen, Norway, for determining the $\mathrm{G}+\mathrm{C}$ content.

\section{REFERENCES}

1. Andersson, S. S., J. R. Baker, J. H. Prime, and A. Baird. 1979. Mortality in grey seal pups: incidence and causes. J. Zool. 189: 407-417.

2. Baker, J. R. 1980. The pathology of the grey seal (Haliochoerus grypus). II. Juveniles and adults. Br. Vet. J. 136:443-447.

3. Baker, J. R. 1989. Natural causes of death in non-suckling grey seals (Haliochoerus grypus). Vet. Rec. 125:500-503.

4. Baker, J. R., S. S. Anderson, J. H. Prime, and A. Baird. 1980. The pathology of the grey seal (Haliochoerus grypus). I. Pups. Br. Vet. J. 136:401-412.

5. Bergman, A., B. Järplid, and B. M. Svensson. 1990. Pathological findings indicative of distemper in European seals. Vet. Microbiol. 23:331-341

6. Carter, G. R., and S. V. Rundell. 1975. Identification of type A strains of $P$. multocida using staphylococcal hyaluronidase. Vet. Rec. 96:343. 
7. Coykendall, A. L. 1970. Base composition of deoxyribonucleic acid isolated from cariogenic streptococci. Arch. Oral Biol. 15:365-368.

8. Geraci, J. R., D. J. St. Aubin, I. K. Barker, R. G. Webster, W. S. Hinshaw, W. J. Bean, H. L. Ruhnke, J. H. Prescott, G. Early, A. S. Baker, S. Madoff, and R. T. Schooley. 1982. Mass mortality of harbour seals: pneumonia associated with influenza A virus. Science 215:1129-1131.

9. Gilmour, M. N., T. S. Whitam, M. Kilian, and R. K. Selander. 1987. Genetic relationships among the oral streptococci. J. Bacteriol. 169:5247-5257.

10. Heide-Jørgensen, M.-P., T. Härkönen, R. Dietz, and P. M. Thompson. 1992. Retrospective of the 1988 European seal epizootic. Dis. Aquat. Org. 13:37-62.

11. Heje, N. I., P. Henriksen, and B. Aalbak. 1991. The seal death in Danish waters 1988. I. Pathological and bacteriological studies. Acta Vet. Scand. 32:205-210.

12. Katafos, F. C., C. W. Jones, and A. Efstradiadis. 1979. Determination of nucleic acid sequence homologies and relative concentrations by a dot hybridization procedure. Nucleic Acids Res. 7:1541-1552.

13. Krogsrud, J., Ø. Evensen, G. Holt, S. Høie, and N. H. Markussen. 1990. Seal distemper in Norway in 1988 and 1989. Vet. Rec. 126:460-461.

14. Lancefield, R. C. 1933. A serological differentiation of human and other groups of hemolytic streptococci. J. Exp. Med. 57:571-595.
15. Marmur, J., and P. Doty. 1962. Determination of the base composition of deoxyribonucleic acid from its thermal denaturation temperature. J. Mol. Biol. 5:109-118.

16. Munro, R., H. Ross, C. Cornwell, and J. Gilmour. 1992. Disease conditions affecting common seals (Phoca vitulina) around the Scottish mainland, September-November 1988. Sci. Total Environ. 115:67-82.

17. Sneath, P. H. A., N. S. Mair, M. E. Sharpe, and J. G. Holt (ed.). 1986. Bergey's manual of systematic bacteriology, vol. 2, p. 10431071. The Williams \& Wilkins Co., Baltimore.

18. Southern, E. M. 1975 . Detection of the specific sequences among DNA fragments separated by gel electrophoresis. J. Mol. Biol. 98:503-517.

19. Steiger, G. H., J. Calambokidis, J. C. Cubbage, D. E. Skilling, A. W. Smith, and D. H. Gribble. 1989. Mortality of harbour seal pups at different sites in the inland waters of Washington. J. Wild. Dis. 25:319-328.

20. Stoner, R. A. 1978. Bacitracin and coagglutination for grouping of $\beta$-hemolytic streptococci. J. Clin. Microbiol. 7:463-466.

21. Stroud, R. K. 1979. Causes of death in marine mammals stranded along the Oregon coast. J. Wild. Dis. 15:91-97.

22. Tønjum, T., G. Bukholm, and K. Bøvre. 1990. Identification of Haemophilus aphrophilus and Actinobacillus actinomycetemcomitans by DNA-DNA hybridization and genetic transformation. J. Clin. Microbiol. 28:1994-1998. 